\title{
Enerji Verimliliği ve Tasarrufunda Tüketici Algı Yönetimi Yöntemlerinin Değerlendirilmesi
}

\author{
Tuba Benek Arslan ${ }^{1}$, Şafak Baykal ${ }^{2}$, Alper Terciyanlı $^{3}$, Ertuğrul Çam ${ }^{*}$ \\ ${ }^{1}$ Endoks Enerji Dağıtım Sistemleri Ltd., Ankara, Türkiye (ORCID: 0000-0003-1790-2935), tuba.benek@endoks.com \\ ${ }^{2}$ Inavitas Enerji A.Ş., Ankara, Türkiye (ORCID: 0000-0002-5519-6077), safak.baykal@inavitas.com \\ 3 Inavitas Enerji A.Ş., Ankara, Türkiye (ORCID: 0000-0003-2671-2615), alper.terciyanli@inavitas.com \\ $4^{4 *}$ Samsun Üniversitesi, Mühendislik Fakültesi, Samsun, Türkiye, (ORCID: 0000-0001-6491-9225), ertugrul.cam@samsun.edu.tr
}

(Illk Geliş Tarihi 3 Mayıs 2021 ve Kabul Tarihi 4 Kasım 2021)

(DOI: 10.31590/ejosat.932265)

ATIF/REFERENCE: Benek Arslan, T. \& Baykal, Ş., Terciyanlı, A. \& Çam, E. (2021). Enerji Verimliliği ve Tasarrufunda Tüketici Alg1 Yönetimi Yöntemlerinin Değerlendirilmesi. Avrupa Bilim ve Teknoloji Dergisi, (27), 710-717.

\section{$\ddot{O} \mathbf{z}$}

Dünya genelindeki enerji talebinin hızla artması ve buna bağlı olarak ekosistem dengesinin bozulmasının önlenmesi için çevreyi koruma yaklaşımlarının yanı sıra enerji kullanımı üzerindeki yaklaşımlar da önemlidir. Enerji kaynaklarının yetersizliği, enerji verimliliği ve enerji tasarrufu konularının önemini artırmıştır. Mevcut uygulamalar daha çok teknolojik iyileştirme ve yenilikler ile enerji tüketimini azaltmayı amaç edinen enerji verimliliği çalışmalarıdır. Ancak, bu çalışmalarda başarı elde etmenin en önemli yöntemlerinden biri de tüketici davranışlarını daha iyi anlamak, tüketici davranışının etkilendiği dinamiklerin farkında olmak ve tüketicileri bu konuda bilinçlendirerek enerji verimliliği uygulamalarına etkin bir şekilde dahil etmektir. Bu makalede, enerji verimliliği ve tasarrufların sağlanması noktasında tüketici algı yönetiminin önemi incelenecek ve mevcut uygulamaların bir değerlendirmesi sunulacaktır.

Anahtar Kelimeler: Enerji Verimliliği, Enerji Farkındalığı, Talep Tarafı Katılımı, Müşteri Bağlılığı, Müşteri Deneyimi, Tüketici Algı Yönetimi

\section{Evaluation of Consumer Perception Management Methods in Energy Efficiency and Saving}

\begin{abstract}
With the rapid increase in energy demand around the world and the deterioration of the ecosystem balance, the approaches on energy use are also important in addition to protecting the environment. At this point, the insufficiency of energy resources has increased the importance of energy efficiency and energy-saving issues. Current applications are energy efficiency studies that aim to reduce energy consumption with mostly technological improvements and innovations. However, one of the most important methods of achieving success in these studies is to better understand consumer behavior, to be aware of the dynamics that affect consumer behavior, and to effectively include consumers in energy efficiency applications by raising awareness on this issue. In this article, the importance of consumer perception management in energy efficiency and savings will be examined and an evaluation of current applications will be presented.
\end{abstract}

Keywords: Energy Efficiency, Energy Awareness, Demand Response, Customer Engagement, Customer Experience, Consumer Perception Management 


\section{Giriş}

Küresel enerji talebi günden güne artmaktadır. Özelikle gelişmiş ülkelerde talep arttıkça büyük miktarda enerji tüketmeye devam etmektedirler (BP, 2019). Dünya Enerjisi istatistiksel İncelemesi Raporu'na göre, toplam dünya enerji tüketimi 2019 'da 13.864,9 Mtoe artmıştır (BP, 2019). Energy Information Administration (EIA)'nın 2019 yılındaki raporuna göre, 2050 yılına kadar dünya enerji tüketiminin yaklaşık olarak \%50 oranında artacaktır (EIA, 2019). Dünyadaki ülkelerin karşılaşmış olduğu enerji ile ilgili problemler; fosil yakıt rezervlerinin azalması, sürdürülebilir enerji tedariğinin sağlanması ve küresel 1sınmanın etkilerinin artmasıdır (MacKay, 2008).

Elektrik enerjisinin kullanımının, diğer enerji kaynaklarının kullanımını 25 yılda katlayacağını belirten EIA, elektrik üzerine ayrıca odaklanmaktadir. International Electrotechnical Commission (IEC) birinci enerji kaynağı olan elektriğin, akıllı ve ekonomik kullanımının, enerji problemlerini çözmek için en önemli faktör olduğunu belirtmekte ve bunun da yenilenebilir enerji kaynaklarından enerji üretiminin yanı sıra verimli enerji kullanımı ile de olacağını söylemektedir (International Energy Agency, 2018). Ayrıca IEC, enerji verimliliği konusunun sadece daha az elektrik kullanımı ile değil; aynı zamanda sistemlerin ve sosyal davranışların değişmesi ile de bağlantılı olduğunun altını çizmiştir. Pozitif davranış değişiminin ev sakinlerine evdeki cihazların ne kadar enerji kullandığını gösteren bildirimler sağlanarak başarılabileceği belirtilmektedir (Ueno, Inada, Saeki, \& Tsuji, 2006). Yapılan farklı literatür çalışmalarında cihaz bazında kullanım bilgisine dayanan enerji tüketimi stratejisi uygulayarak enerji korunumunun $\% 9$ ile $\% 20$ aralığında elde edilebileceğini göstermiştir.

Potansiyel enerji tasarruflarını ve buna bağlı olarak parasal tasarrufların yanında artan konfor ve hava kalitesinin iyileşmesi gibi diğer yararları tüketicilere bildirmek, verimsiz cihazların değiştirilmesi konusunda motivasyonun artmasına neden olarak tüketimi kalıcı olarak azaltabileceği düşünülmektedir.

$\mathrm{Bu}$ makalede, ilk olarak talep tarafı katılımı ile enerji verimliliği sağlanması yönünde Dünya'da gerçekleştirilmiş uygulamalar ele alınmaktadır. Daha sonrasında yapılan uygulamaların gözden geçirme ve değerlendirme sonuçları ile tüketici/kullanıcı davranışının hanelerdeki enerji verimliliği üzerindeki potansiyel etkileri ortaya konulmaktadır.

\section{Materyal ve Metot}

\subsection{Enerji Verimliliği ve Tüketici Farkındalığı}

Dünya genelinde enerji talebi hızla artarken; küresel olarak artan gelir düzeyleri, kentleşme ve elektriğe erişimin artması enerji talebinin hızla artmasına neden olmaktadır. Bu sebeple de kaynakları hızla tükenmekte olan dünyamızda, kullanılan enerji miktarının hızla artması ve buna bağlı olarak ekosistem dengesinin bozulması sadece çevreyi koruma konusunda değil, aynı zamanda enerji kullanımı üzerinde de yeni yaklaşımların oluşmasına neden olmuştur. Sanayileşme, hayat standartlarının yükselmesi ve gelişen teknolojiyle birlikte teknolojik ürün kullanımının artması ve artan nüfus sebebiyle, enerji tüketimi dünya genelinde bir artış göstermektedir.

Enerji verimliliği, binalardaki yaşam standardını ve hizmet kalitesini artırırken, endüstriyel işletmelerde üretim kalitesi ve miktarında düşüşe yol açmadan, birim hizmet veya ürün miktarı başına enerji tüketiminin azaltılmasıdır. Daha geniş bir biçimde e-ISSN: 2148-2683 enerji verimliliği; gaz, buhar, 1S1, hava ve elektrikteki enerji kayıplarını önlemek, çeşitli atıkların geri kazanımı ve değerlendirilmesi veya ileri teknoloji ile üretimi düşürmeden enerji talebini azaltması, daha verimli enerji kaynakları, gelişmiş endüstriyel süreçler, enerji geri kazanımları gibi etkinliği artırıcı önlemlerin bütünüdür (Turhan, ve diğerleri, 2010).

Enerji tasarrufu, tüketiciler tarafından alınan yaşam şartlarını etkileyecek önlemler ile kullanılan enerji tüketimindeki düşüş, rakamsal olarak \%10-\%20 civarında ifade edilmektedir (Topal \& Özoğlu, 2018).

Enerji verimliliğini sağlamak ve devamlı kılmak birçok yöntem ile mümkündür. $\mathrm{Bu}$ yöntemlerin çoğu teknolojik müdahaleleri içerir, ancak enerji tüketimindeki farkındalıklar da dahil olmak üzere bazı önlemler tüketici davranışlarına dayanmaktadır. Tüketiciler arasında enerji tasarrufu bilincini vurgulamak iki ana bileşen olan bilgi ve uygulama ile sağlanabilmektedir.

Fragidis'e (Fragidis \& Detlef, 2015) göre, enerji farkındalığı, ne kadar enerji tüketildiği konusundaki bilgileri içermektedir. Tüketicilerin enerji tüketimini azaltmaları gerekir, ancak bununla ilgili bilgi sahibi olmadıkları için nasıl yapılacağını bilmemektedirler. Daha da önemlisi, tüketicilerin enerji tüketimi hakkında ne kadar elektrik kullandıkları ne zaman kullandıkları ve aylık elektrik faturalarını en iyi şekilde etkilemenin zamanı gibi ayrıntıları bilmeleri gerekir. Hem de ne kadar bilgili olurlarsa, enerji tasarrufu uygulamalarını benimsemeye o kadar ilgi duyabilirler. Enerji tüketicilerinin farkındalığı, enerji tasarrufu davranışlarını benimsemenin ilk adımıdır (Fragidis \& Detlef, 2015). Tüketiciler her ne kadar enerji tasarrufu konusunda yeterli bilgiye ve bunları hayata geçirme isteğine sahip olsalar da birçok tüketici hala enerji verimliliği sağlamaya ve korumaya yönelik kayda değer ilerlemeler göstermemektedir. Enerji tasarrufuna yönelik enerji bilinci, ev sakinlerinin uygun bir tutumu ve insan davranışını gerektirir (Majid, Salehudin, Rahim, \& Othman, 2016) . Bu durumda tüketicilerin enerji verimliliği konusunda farkındalığının artmasının, tüketim davranışlarını etkileyebileceği ortadadır.

Nijerya'da yapılan bir başka çalışmada, önceden belirlenmiş konut örneklerinde enerji verimliliğini etkileyen faktörler ele alınmıştır. Çalışmanın sonuçları meskenlerde enerji verimliliği ile tutum ve davranış arasında güçlü bir korelasyon olduğunu göstermiştir. Buna ek olarak, aynı araştırmacılar aynı meselelerle sosyal bir araştırma yapmış ve Nijerya'nın Bouchi kasabasında spesifik enerji verimliliği dağıtımının imalarına odaklanmıştır (Hussaini \& Majid, 2014). Sonuç, bina sakinlerinin büyük ölçüde farkındalık ve gerekli enerji verimliliği bilgisi eksikliği nedeniyle, daha düşük bir enerji verimliliği uygulaması ortaya koymaktadır. Ayrica, Syed Hussain (Hussain, Ismail, \& Noh, 2013) Malezya Utara Üniversitesi'nde (UUM) öğrenciler arasında enerji tasarrufu bilincini araştırmak için bir çalışma yapmıştır. Bu araştırma bilgi, görüş ve eylem olmak üzere üç ana unsuru içermektedir. Sonuçlar, UUM öğrencileri arasında enerji tasarrufu konusunda farkındalık düzeyinin düşük olduğunu ve bunun elektrik faturalarının maliyetini ödemek açısından üniversite yönetiminde büyük bir yük oluşturduğunu ortaya koymuştur. $\mathrm{Bu}$ nedenle, UUM öğrencileri arasında elektrik tasarrufu bilincini artırmak amacıyla daha fazla çaba harcanması gerektiği önerilmiştir. Aynı şekilde, Noor Hanita'ya (N.H. Abdul Majid, 2011) göre farkındalık ve sosyal statü gibi faktörlerin enerji 
verimliliği farkındalığı üzerinde etkileri olabilir, ancak bunu mutlaka belirlemek gerekmez. Ayrıca, enerji tüketimini azaltmak için hanelerde enerji verimliliği uygulamalarının ihtiyaçlarının karşılanmasını önermişlerdir. Buna paralel olarak, çalışmanın sonuçları bireyin farkındalık ve eğitim düzeylerinin Enerji Verimliliği uygulamasını etkilediğini ortaya atmıştır.

Burada adı geçen çalışmalardan hareketle enerji davranışı, tüketicinin iç ortam sağlığını kontrol etmek, binaların içinde termal, görsel ve akustik konfor elde etmek için bina sistemleriyle olan etkileşimidir. $\mathrm{Bu}$ anlamda tüketicinin enerji davranışını etkileyen birçok parametre bulunmaktadır.

\subsection{Enerji Davranışını Etkileyen Parametreler}

Enerji davranışları, binalarda ve konutlarda son kullanım enerji verimliliğinin artması için önemli bir kullanılmayan potansiyeli temsil etmektedir. Enerji davranışları, binalardaki enerji kullanımının önemli bir belirleyicisi olsa da davranışa bağlı enerji tasarrufu potansiyeli, teknolojik çözümlerden gelenler kadar yüksek seviyelerde de olabilmektedir. Tüketicilerin enerji davranışı birçok farklı parametreden etkilenmektedir.

$\mathrm{Bu}$ parametrelerden konfor (özellikle termal konfor), tüketicinin enerji kullanımını doğrudan etkileyen kişisel (fizyolojik, psikolojik) ve sosyal parametreler nedeniyle kişiden kişiye değişen bir zihin halidir. Fabi, Andersen (Fabi V, 2012), bina sakinlerinin pencere açma davranışlarını inceleyerek bu durum üzerindeki etkili parametreleri belirleyip, bu parametreleri fiziksel çevresel faktörler, bağlamsal faktörler, psikolojik faktörler, fizyolojik faktörler ve sosyal faktörler olmak üzere beş gruba ayırmıştır.

Dış ortam sıcaklığı, bağıl nem, güneş radyasyonu, rüzgâr ve iklimsel (çevresel, fiziksel) parametreler, tüketicilerin termal konfor elde etmek için bina sistemleriyle etkileşimlerini etkileyen diğer önemli parametrelerdir. Bir araştırma çalışmasında (Rijal HB, 2011), farklı hücresel ofislerden oluşan bir ofis bloğunun bir örneğinde her hücresel ofisin bir penceresi olduğu ve bir kişi tarafından kullanıldığı düşünülmüştür; dış havanın soğuk ve tüm pencerelerin de kapalı olduğu varsayılmıştır. Oda sıcaklığının kademeli olarak artması durumunda, daha fazla tüketicinin çok sıcak hissettiği ve pencerelerini açtığı görülmüştür. $\mathrm{Bu}$ araştırmanın sonucu, farklı senaryolar kullanarak diğer etkinliklere genişletilebilen açık pencerelere sahip olma olasılığını göstermek için bir eğri olarak sunulabilir. İklim parametrelerinin tüketicilerin enerji davranışları üzerindeki etkisi, farklı iklim koşulları için yaygın olarak incelenmiştir. Bu parametreler zamana/tarihe bağlıdır, bu nedenle birçok çalışmada potansiyel sonuçların olasılığını tahmin etmek için stokastik modeller kullanılır. Tüketicilerin gerçek etkileşimlerinin veya enerji davranışı anketlerinin izlenmesi için yıl boyunca termal ölçümler tanıtılmakta ve bu iklimsel çalışmalarda kullanılmaktadır (Rijal HB T. P., 2011).

Bina tipi aktivitenin türünü, giyim tipini, metabolik 1sı üretimini, tüketicilerin özel ihtiyaç ve beklentilerini aynı zamanda bina sistemleri ile olası etkileşim derecelerini belirlemeye yardımcı olmaktadır. Konut binalarına ve ofislere verilen dikkat seviyesi, inşaat sektöründeki toplam enerji tüketimi üzerindeki kritik etkilerinden kaynaklanmaktadır. Bazı çalışmalar ticari ve eğitim binalarını sınırlı bulgularla araştırmıştır. Sergiler ve sağlık merkezleri gibi diğer kamu binası türleri üzerinde daha seyrek çalışmalar yapılmıştır (Chen J, 2014).

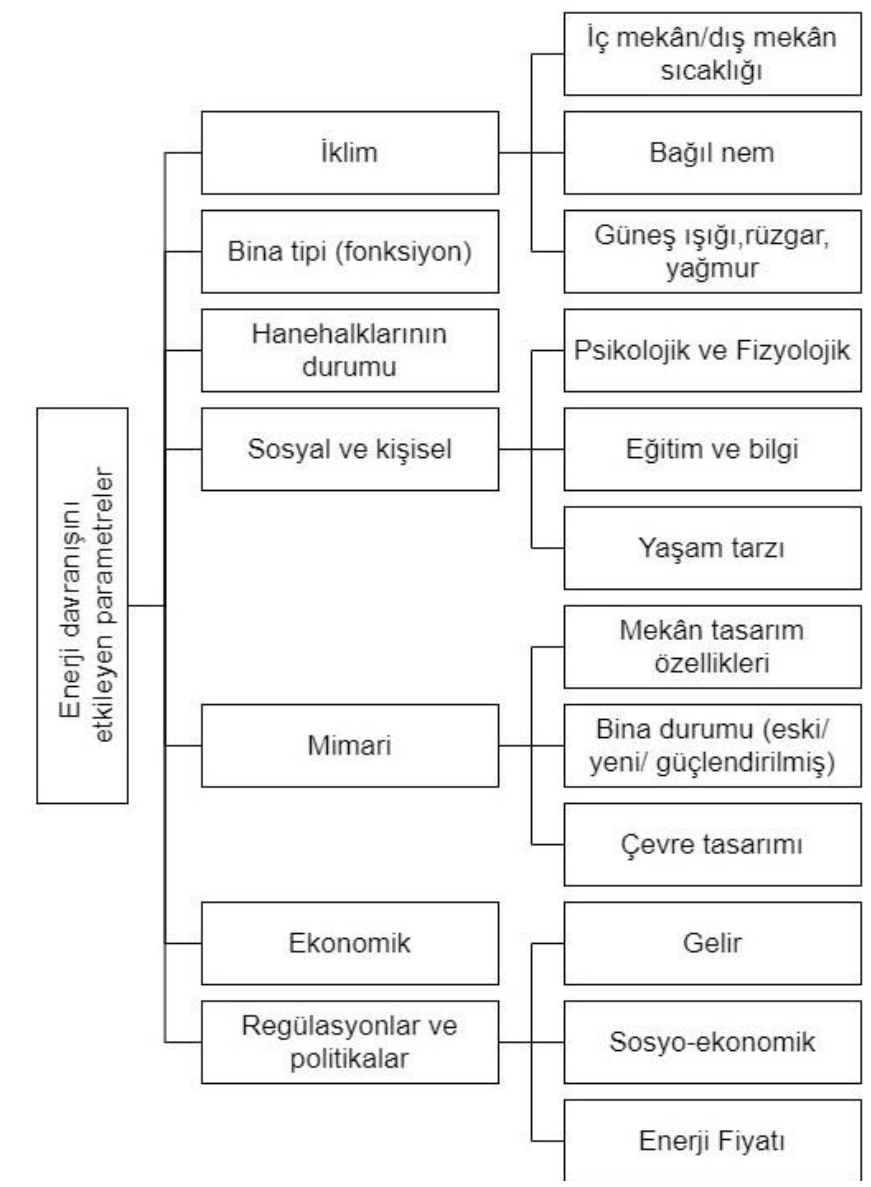

Şekil 1 Enerji Davranışını Etkileyen Parametreler

Sosyal ve kişisel (psikolojik ve fizyolojik) parametreler, tüketicilerin konfor ve enerji tutumunda önemli bir rol oynamaktadır ve literatürde de geniş bir şekilde incelenmiştir. Martinaitis, Zavadskas (Martinaitis V, 2015), hanehalklarının enerji davranışlarını etkileyen sosyal ve kişisel faktörleri kullanıcıların enerji sorunları, cinsiyet, yaş, istihdam, aile büyüklüğü ve sosyo-kültürel aidiyet konusundaki farkındalığg olarak belirlemiştir. Bazı çalışmalar bir sosyal veya bireysel parametreyi tartışmıştır; örneğin, erkek ve kadının termal tercihleri arasındaki farklar bazı bilim adamları tarafından belirtilmiştir (Indraganti M, 2015). Bununla birlikte, bu alandaki sosyal ve kişisel faktörlerle ilgili en güvenilir ve kapsamlı çalışmalar, ofis binalarındaki tüketicilerin elektrik tüketimini incelemek için Tetlow, van Dronkelaar tarafından insan davranış teorilerini kullanarak iki parametreyi birleştirmesidir. Buna ek olarak, bazı bilim adamları, binalardaki enerji tüketimi tahminlerinin doğruluğunu artırmak için tüketicilerin davranışlarının sosyolojik yönlerini düzenleyen daha ayrıntılı niceliksel çalışmalar önermektedir (Tetlow RM, 2015).

Enerji fiyatı ve istihdam gibi enerji düzenlemeleri ve ekonomik parametreler çeşitli çalışmalarda tartışılmıştır. Araştırmalar, tüketicilerin elektrik faturalarını ödemekten doğrudan sorumlu olduklarında, enerji tasarrufu konusunda daha dikkatli davrandıklarını göstermektedir. Park ve Kim tarafından yapılan çalışmanın bulgularına göre (Park JS, 2012), ankete katılanların yarısından fazlası, mekanik fanların kullanımından kaçınmanın ve bir miktar rahatsızlık duymanın ana nedeni olarak enerji maliyetlerini göstermiştir. Sonuç olarak tüketicilerin, ekonomik durumunun konutlarının kalitesini ve boyutunu 
belirleyebileceğini bunun sonucunda da enerji tüketimini etkileyeceği bulgusu ortaya çıkmıştır.

Mimarinin ve iç tasarım özelliklerinin tüketicilerin enerji davranışları üzerindeki etkisi geniş bir şekilde incelenmiştir. Mekânın iç tasarımı, bina açıklıklarının (pencere ve kapılar) görsel kalitesi, mimari dolaşım ve renkler, iç mekanların malzeme ve kompozisyonları da dahil olmak üzere, tüketicilerin davranışlarını farklı şekillerde etkileyebilmektedir. Ayrıca, aydınlatma tasarımı ile tüketicinin aydınlatma tüketimi de farklı çalışmalarda ele alınarak tüketicinin enerji davranışı üzerine olası etkileri ele alınmıştır. Gandhi ve Brager (Gandhi P, 2016), tüketicilerin ofis binalarındaki fiş yükü (elektrik ve aydınlatma) enerji tüketimi üzerindeki etkisini araştırmıştır.

\section{Araştırma Sonuçları ve Tartışma}

\subsection{Enerji Davranıșı Uygulamalarının İncelenmesi}

Dünya'da birçok farklı ülkede hanehalkının tüketim performansını ve enerji davranışını gözlemlemek amacıyla farklı uygulamalar gerçekleştirilmiştir. Bu uygulamalar aracılığıyla tüketicilerin enerji kullanım davranışları ve kullanım sonrası enerji kullanımı değerlendirmesi çok sayıda araştırma projesinde ve raporlarında analiz edilmiştir.

Avrupa Çevre Ajansı (EEA) tarafından 2013 yılında yayımlanan "Davranış değişikliği yoluyla enerji verimliliğine ulaşmak: Ne gerekiyor?" raporu (European Environment Agency (EEA), 2013) enerji verimliliği sağlamak için tüketici davranışında değişikliği hedefleyen birtakım faaliyetleri ortaya koymaktadır.

Raporda verilen enerji verimliliğini sağlamak amacıyla kişilerin davranış değişikliğini hedefleyen faaliyetlere bağlı olarak Tablo 1'de verildiği üzere yaklaşık \%5-\%20 aralığında bir enerji tasarrufu potansiyeli olduğunu ortaya koymaktadır.

Tablo 1. Davranışı hedefleyen önlemler sayesinde elde edilebilecek potansiyel enerji tasarrufu

\begin{tabular}{lc}
\hline \multicolumn{1}{c}{ Faaliyet } & $\begin{array}{c}\text { Potansiyel Enerji } \\
\text { Tasarrufu }\end{array}$ \\
\hline $\begin{array}{l}\text { Geri Bildirim } \\
\text { Doğrudan geri bildirim- } \\
\text { sayaçlar ve ev içi ekranlar (In-Home } \\
\text { Display (IHD) }\end{array}$ & $5-15 \%$ \\
\hline $\begin{array}{l}\text { Dolayll geri bildirim- } \\
\text { faturalandırma, kelişmişs } \\
\text { belirleme ve geri bildirim } \\
\text { hedef }\end{array}$ & $2-10 \%$ \\
\hline $\begin{array}{l}\text { Kişisel hedef belirleme ve geri } \\
\text { bildirim }\end{array}$ & $5-15 \%$ \\
\hline $\begin{array}{l}\text { Enerji denetimleri } \\
\text { Toplum temelli girişimler }\end{array}$ & $5-20 \%$ \\
\hline $\begin{array}{l}\text { Diğer önlemler (Bina sertifikasyonu } \\
\text { ve etiketleme, Eko-tasartm, Müşteri } \\
\text { Katılımı) }\end{array}$ & $5-20 \%$ \\
\hline
\end{tabular}

Enerji verimliliği konusunda davranış değişikliği hedefleyen faaliyetlerden "Geri Bildirim" enerji bilincinin artırılması ve tüketicilerin enerji tüketimine yönelik tutumlarının değiştirilmesinde önemli bir rol oynamaktadır. Bu nedenle enerji verimliliğinin artırılmasına yönelik geri bildirim uygulamaları bu bölümde ele alınmıştır.

\subsubsection{Geri Bildirim Yöntemleriyle Tüketici Algısı Yönündeki Uygulamalar}

Geri bildirim, etkili öğrenmede temel bir unsurdur: bu, ev içi ve ev dışı ortamlar için eşit derecede geçerlidir.

$\mathrm{Bu}$ noktadan hareketle akıllı sayaçların, doğrudan geri bildirim kapsamında değerlendirildiği görülmektedir. Özellikle Avrupa çapında ilgi çekici eve geri bildirim yoluyla hanehalkının enerji verimliliği konusunda farkındalığını artıran ve bu sayede de enerji davranışı değişikliği yaratabilen akıllı sayaçların yaygınlaştırılması noktasında Dünya çapında da bir takım yaygınlaştırma çalışmaları gerçekleştirilmiştir. $\mathrm{Bu}$ konuda Danimarka, Amerika, İsveç ve İngiltere de gerçekleştirilmiş çalışmalar ve sonuçları incelenmiştir.

Danimarkalı bir enerji şirketi olan NRGi, 2009 ve 2012 yılları arasında müşteri tabanına 210.000 akıllı sayaç kurmuştur. Programın temel amacı, özellikle yenilenebilir enerji ve elektrikli araçların kullanımında beklenen artışı da göz önüne alarak bu yükü yayabilmek adına ve şebekeyi sürdürmenin daha ucuz yolları ile kendi şebeke altyapısını ve hizmet ağlarını geleceğe hazırlamaktır. $\mathrm{Bu}$ çalışma daha çok şebeke altyapısını güçlendirmeye yönelik bir çalışma olup burada tüketici davranışını değiştirmek veya enerji tasarrufu sağlamak programa özel olarak dahil edilmemiştir. Buna rağmen sahada akıllı sayaç kurulumları sırasında karşılan en büyük zorluklardan biri, müşterilere neden yeni bir sayaca ihtiyaç duyulduğu ve neden yeni özelliklerin eklendiğini açıklamak olduğu görülmüştür. Müşteriler, enerji tüketimini akıllı telefon veya Web üzerinden görüntüleme seçeneğine sahip olmasına rağmen tüketicilerin bu geri bildirim seçeneklerine çok fazla ilgi göstermediği gözlemlenmiştir. $\mathrm{Bu}$ noktada da tüketicilere ürünün tüm faydalarını net bir şekilde ifade etme ve bu sayede gerek kullanım gerekse enerji verimliliği farkındalığı yaratılması gerekliliği ortaya konulmuştur.

Tablo 2. Enerji tüketimiyle ilgili geri bildirim türleri

\begin{tabular}{|c|c|}
\hline \multicolumn{2}{|c|}{ Geri Bildirim Türleri } \\
\hline $\begin{array}{l}\text { Doğrudan } \\
\text { Bildirim }\end{array}$ & $\begin{array}{ll}\text { - } & \text { PC üzerinden etkileşimli geri } \\
\text { bildirim } \\
\text { - } & \text { Akıllı Sayaçlar } \\
\text { - } & \text { Tetikleyici cihazlar/ Tüketim } \\
\text { limitleyiciler } \\
\text { - } \\
\text { - } \text { Ön ödemeli sayaçlar } \\
\text { - } \quad \text { Kendi-kendine sayaç okuma } \\
\text { - } & \text { Malişman ile sayaç okuma } \\
& \text { Mösteren prizler }\end{array}$ \\
\hline
\end{tabular}




\begin{tabular}{lllr}
\hline $\begin{array}{l}\text { Dolaylı } \\
\text { Bildirim }\end{array}$ & Geri & $\bullet$ & $\begin{array}{l}\text { Sayaç okumalarına göre daha } \\
\text { s1k faturalar }\end{array}$ \\
& $\bullet$ & $\begin{array}{l}\text { Okumalara ve geçmiş geri } \\
\text { bildirimlere dayalı } \\
\text { faturalar }\end{array}$ & sik \\
& &
\end{tabular}

- Okumalara ve normatif geri bildirimlere dayalı s1k faturalar (benzer haneler ile k1yasama)

- Sik faturalar ve ayrıştırılmış geri bildirimler

- Sik faturalar ve verimlilik önlemlerinde denetim teklifleri veya indirimler

- Sik faturalar ve ayrıntılı yıllık veya üç aylık enerji raporları

\begin{tabular}{lll}
\hline Kasıtsız Geri & - & $\begin{array}{l}\text { Yeni enerji kullanan ekipman } \\
\text { Bildirim }\end{array}$ \\
& Dağıtık yenilenebilir enerji \\
& üretimi \\
& $\begin{array}{l}\text { Topluluk enerji tasarrufu } \\
\text { projeleri ve sosyal öğrenme } \\
\text { potansiyeli }\end{array}$ \\
\hline Enerji & Müşterinin inisiyatifiyle bir \\
Denetimleri & anketör tarafindan yapılan \\
& $\begin{array}{l}\text { Bir ev satışının veya diğer } \\
\text { zorunlu araştırmanın bir } \\
\text { parçası olarak yapılan } \\
\text { Tüketici tarafindan gayri } \\
\text { resmi olarak yürütülen }\end{array}$ \\
\hline
\end{tabular}

Amerika Birleşik Devletleri'nde, Federal Enerji Düzenleme Komisyonu (FERC) tarafindan enerji hizmet şirketleri arasında gelişmiş ölçüm kullanımı konusunda bir anket yapılmıştır. Bu, ankete katılan kamu hizmetlerinin \%66'sının müşteri hizmetlerini geliştirmek için gelişmiş ölçüm kullandığını, \%53'ünün kesinti ve diğer hat kayıplarını tespit etmek için, \%42'sinin sağlanan elektriğin kalitesini iyileştirmek için, \%39'unun varlık yönetimi için ve yalnızca \%19'unun talep yanıtını teşvik etmek için kullandığını ortaya konulmuştur.

Bunun yanında İsveç’te akıllı sayaçların yaygınlaştırılması ve tüketicinin programa dahil olması ile alakalı olarak; İsveç'te sayaç dağıtım programı 2006 'da başlamıştır. Bunu takiben 2009'da ülke çapındaki 5,2 milyon müşterinin tümü için zorunlu aylık sayaç okumasının başlatılmasıyla da sonuçlanmıştır. Ekim 2012 itibariyle, tüm müşteriler isterlerse saatlik okumalara sahip olabilir, ancak bu ayrıntı, üçüncül ve endüstriyel sektörlerdeki müşteriler için zorunlu hale getirilmiştir. Mayıs 2012'de İsveç hükümeti, rolü 'akıllı şebeke alanındaki farklı aktörler arasında iş birliği ve bilgi aktarımını koordine etmek ve teşvik etmek ve İsveç'te akıllı şebekenin gelişimini hızlandırmak için teklifler sunmak' olan Akıllı Şebeke Koordinasyon Konseyi'ni atamıştır. İsveç'te, elektrik faturalandırması şikayetlerin bir numaralı nedeni olduğundan tahminler yerine gerçek tüketim verilerine dayalı daha doğru faturalandırma, akıllı sayaç kullanımının ana nedeni olmuştur.

$\mathrm{Bu}$ çalışma ile İsveç, iletim ve dağıtım sistemindeki enerji kaybında yaklaşık \%9'luk azalma gibi orijinal kapsamın ötesinde da faydalar sağladığı görülmüştür. İsveç deneyiminde akıllı sayaçların tanıtılmasıyla kolaylaştırılan daha ilgili tüketicilere sahip olmanın ön koşulları olarak aşağıdakileri içermesi gerektiği ortaya konulmuştur:

\section{i. Dinamik fiyatlandırma}

ii. Müşteriye sağlanan fatura bilgilerinde, son kullanıcı fiyatını oluşturan çeşitli unsurlar (şebeke tarifeleri, vergiler, vb.) arasında net bir ayrım

iii. Tedarikçiler arasında veya aynı tedarikçi tarafından sunulan farklı hizmetler arasında seçim yapma seçenekleri

iv. Tüketim değişiminin elektrik maliyeti üzerindeki etkisine ilişkin net bilgiler (örneğin yoğun dönemden yoğun olmayan dönemlere).

Bu çalışmaların yanı sıra, akıllı sayaçların piyasaya sürülmesi ile tüketicilerin enerji tüketimlerini izleyebileceği zorunlu bir Ev İçi Ekran (IHD- In Home Display) kullanımını da beraberinde gerektirmektedir. Bu sayede Tüketiciler bu IHD üzerinden enerji tüketimlerini izleyebilmekte ve tüketimlerinin farkında olabilmektedirler.

2019 yılında bağımsız pazar araştırma ajansı Future Thinking İngiltere'de BEAMA'nın üyelerinin sunduğu IHD tasarımlarının ve hizmetlerin sürekli iyileştirilmesini ve tüketicilerin enerji verileri yolunda ne beklediğini anlamasını sağlamasına yardımcı olmasını hedefleyen bir araştırma çalışması gerçekleştirmiştir (Future Thinking, 2019).

Future Thinking tarafından yürütülen bu araştırmanın amacı, enerji verimliliği konusundaki davranışların, alışkanlıkların ve müşteri anlayış düzeylerinin IHD'lerden nasıl etkilenebileceğini ve IHD'lerin tasarımı ve işlevinin müşterilere nasıl yardımcı olabileceğini keşfetmektir. Yapılan bu araştırmada tüketicilerin davranış ve alışkanlıkların neler olduğu, ev içi ekranların fonksiyonları ve tasarımları ile tüketicilerin (kullanıcıların) anlama düzeyinin ne olduğu araştırılmıştır.

Farklı tüketici türlerinin evlerindeki gerçek davranışlarına ilişkin zengin, "anlık" bir anlayış sağlamak için en uygun araştırma tasarımı olarak nitel bir yaklaşım değerlendirilmiştir. Örneklem olarak farklı müşteri türlerinden seçim yapılarak bir örneklem oluşturulmuştur. Katılımcılar, IHD'yi "en azından ara sıra" kurmuş ve onunla meşgul olduklarına dayanarak çalışmaya alınmıştır. Saha çalışması için iki aşamalı bir yaklaşım kullanılarak, demografik özellikler, yaşam aşamaları, yaşlar, konumlar, IHD'lerle katılım ve kurulumdan bu yana geçen süreyi kapsayan tam denetimli bir grup elde edilmiştir. Araştırma kapsamında 35 yerli enerji tüketicisi dahil edilmiştir.

Yapılan araştırmada katılımcıların, kurulu IHD'lerin farkında olma düzeyleri, kullanım süresi farklı olanlar üzerinden değerlendirilmiştir. Bunun yanında bu cihazların kurulumları açısından, konumlandırılmasıyla oluşabilecek farklılıklar değerlendirilmiştir, bunun için hanehalkının en sık kullandığ alanlarda konumlananlar ile daha az sıklıkta kullanılan odalara yerleştirilmesinden doğan farklılıklar değerlendirilmiştir. Diğer taraftan müşteri deneyimi açısından da bir değerlendirme ele alınmıştır. Araştırma katılımcıları, farklı sayıda kişi yaşayan haneler, hanelerde yaşayan kişilerin çalışma saatleri ve şekillerinin farklılık gösterecek şekilde seçilmesiyle bu hanelerdeki müşteri deneyimi ve bağlılı̆̆ değerlendirilmiştir. Hanelerdeki farklı senaryolar üzerinden davranışsal değişimler gözlemlenmiştir. 
Yapılan saha çalışması ve analiz sonucunda, insanların IHD'leriyle etkileşime geçmek için sahip oldukları temel motivasyonlar maliyetleri azaltmak veya israfı azaltmak olduğu sonucu ortaya çıkmıştır.

Maliyet tasarrufu sağlayanlar, daha düşük gelirleri veya kiralık konutları içerebilen finansal olarak kısıtlı ortamlarda yaşama eğilimindedir. Mali durumlarını yakından izledikleri için IHD'ler üzerinden düzenli olarak enerji tüketimlerini izlemişler ve enerji harcamalarını net bir şekilde bütçelendirebildikleri sonucu ortaya çıkmıştır.

Diğer bir grup olan daha yüksek ve istikrarlı hane gelirine sahip olan katılımcıların motivasyonunun ise "enerji israfindan kaçınmak" olduğu sonucu elde edilmiştir. $\mathrm{Bu}$ grubun motivasyonu enerji verimliliği sağlamaya yöneliktir. Hanelerinde kullanılan ev aletlerinden, enerjinin kullanım noktalarındaki çoğu faaliyetin enerji verimliliği dikkate alınarak gerçekleştirildiği ortaya çıkmıştır.

$\mathrm{Bu}$ kapsamda incelenen farklı geri bildirim projelerinden hareketle doğrudan geri bildirim uygulamaları sonucu elde edilebilecek enerji tasarrufu 5-15\% seviyelerinde olduğu sonucu ortaya konulmuştur.

\subsubsection{Bilgi ve Davranışa Yönelik Uygulamalar}

Enerji verimliliği farkındalığı tüketicilerin enerji verimliliği konusundaki bilgi ve uygulamalarını içeren bir kavramdır. Her iki değişkenin de bir arada bulunması enerji verimli davranışların artmasını sağlamaktadır. $\mathrm{Bu}$ nedenle bu değişkenlerin birbirleriyle ilişkisi oldukça önemlidir. $\mathrm{Bu}$ değişkenlerin birbiriyle ilişkisi, bilgi düzeyleri, davranış ve tutum düzeyi ve bunların farkındalık ile ilişkilerini incelemek amacıyla yapılmış çalışmalar bu bölümde ele alınmıştır.

Uzak Doğu ülkelerinden Malezya Yarımadası'nda, konutlar için enerji verimliliği konusunda tüketici farkındalığ çalışmasında hane halkı enerji tüketiminde insan davranışının etkileri üzerine dört bölgeden 408 katılımcının yer aldığı bir anket uygulaması gerçekleştirilmiştir (Rahman, Leman, Yusof, \& Salleh, 2016). Bu çalışmanın amacı, tüketici farkındalığı bilgisi ve uygulaması olan iki davranışın bir kombinasyonunun ilişkisinin belirlenmesidir.

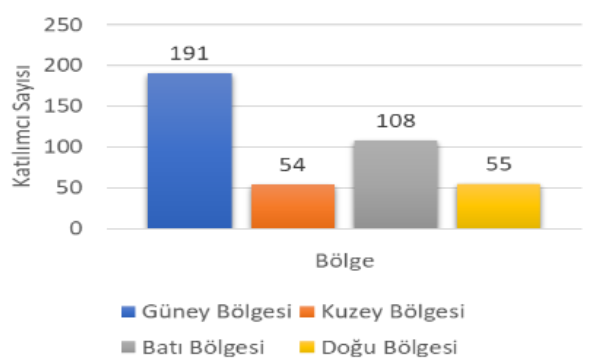

\section{Şekil 2. Bölgelere Göre Anket Katılımcı Sayısı}

Yapılan çalışmada anketler, Kedah, Perlis ve Penang'dan toplamda 54 katılımcının yer aldığı Kuzey bölgesi, Negeri Sembilan, Johor ve Malacca'dan 191 katılımcının yer aldığ Güney bölgesi, Terengganu, Pahang ve Kelantan'dan 55 katılımcının yer aldığı ve Perak, Selangor ve Wilayah Persekutuan'yı içeren Batı Malezya'dan toplamda 108 katılımcının yer aldığı bölgelerde uygulanmıştır.

Anket uygulamalarının sonuçları enerji verimliliği konusunda bilgi ve uygulama olan farkındalığın her iki değişkenine göre aşağıdaki şekilde değerlendirilmiştir.

\section{- Bilgi ve Uygulama İlişkisi}

Bilgi ve uygulama arasında, Tablo 3 'te gösterildiği gibi istatistiksel olarak $(\mathrm{r}=0.348, \mathrm{n}=408, \mathrm{p}<0.01)$ anlamlı ve pozitif yönde bir korelasyon ortaya çıkmıştır. Bu noktada çalışmaya katılan kişilerin bilgi seviyelerinin enerji tüketiminde anlamlı bir ilişkisi olduğunu ve enerji tüketimine etkisi olduğunu söylemek yanlış olmayacaktır

Tablo 3. Bilgi ve Uygulama Arasındaki Korelasyon

\begin{tabular}{|c|c|c|c|}
\hline & & Bilgi & Uygulama \\
\hline \multirow[t]{2}{*}{ Bilgi } & $\begin{array}{l}\text { Pearson } \\
\text { Korelasyon }\end{array}$ & 1 & $0.348 * *$ \\
\hline & $\mathrm{N}$ & 408 & 408 \\
\hline \multirow[t]{2}{*}{ Uygulama } & $\begin{array}{l}\text { Pearson } \\
\text { Korelasyon }\end{array}$ & $0.348 * *$ & \\
\hline & $\mathrm{N}$ & 408 & 408 \\
\hline
\end{tabular}

$* * . p<0.01$

\section{Bilgi ve Farkındalık İlişkisi}

Her iki değişkenin analizinden çıkan sonuçlara bakıldığında $(\mathrm{r}=0.120, \mathrm{n}=408)$ iki değişken arasında anlamlı ve pozitif bir ilişki olduğu ortaya çıkmıştır.

Tablo 4. Bilgi ve Farkındalık Arasındaki Korelasyon

\begin{tabular}{|c|c|c|c|}
\hline & & Farkındalık & Bilgi \\
\hline \multirow[t]{2}{*}{ Farkındalık } & $\begin{array}{l}\text { Pearson } \\
\text { Korelasyon }\end{array}$ & 1 & $0.120 *$ \\
\hline & $\mathrm{N}$ & 408 & 408 \\
\hline \multirow[t]{2}{*}{ Bilgi } & $\begin{array}{l}\text { Pearson } \\
\text { Korelasyon }\end{array}$ & $0.120^{*}$ & \\
\hline & $\mathrm{N}$ & 408 & 408 \\
\hline
\end{tabular}

$* . p<0.05$

\section{Farkındalık ve Uygulama İlişkisi}

Cohen'e göre (Cohen, 1988), Pearson'un $r$ değeri 0,50 ile 1,00 arasında ise korelasyonun güçlü bir ilişkiye sahip olduğunu öne sürmektedir.

Tablo 5. Farkındalık ve Uygulama Arasındaki Korelasyon

\begin{tabular}{|c|l|c|c|}
\hline \multicolumn{2}{|c|}{} & Farkındalık & Uygulama \\
\hline \multirow{2}{*}{ Farkındalık } & $\begin{array}{l}\text { Pearson } \\
\text { Korelasyon }\end{array}$ & 1 & $0.814^{* *}$ \\
\cline { 2 - 4 } & $\mathrm{N}$ & 408 & 408 \\
\hline Uygulama & $\begin{array}{l}\text { Pearson } \\
\text { Korelasyon }\end{array}$ & $0.814^{* *}$ & 1 \\
\cline { 2 - 4 } & $\mathrm{N}$ & 408 & 408 \\
\hline$* * . p<0.01$ & \multicolumn{3}{|l}{} \\
\hline
\end{tabular}

Analiz sonucunda, iki değişken arasında anlamlı ( $\mathrm{r}=0.81, \mathrm{n}$ $=408$ ) ve pozitif yönde güçlü bir ilişki olduğu ortaya çıkmıştır.

$\mathrm{Bu}$ çalışma, sonuç olarak bilgi ve uygulamanın konutlar için enerji verimliliği yaklaşımını uygulamak için farkındalığın ana bileşeni olduğunu ortaya koymuştur. Her iki bileşenin, tüketiciler arasında enerji tasarrufu bilincini artırmak için birlikte uygulamaya konulması gerekliliği ileri sürülmüştür.

Bu yönde yapılan diğer bir çalışma ise Türkiye'de Enerji Verimliliği ve Çevre Dairesi Başkanlığı ile Enerji Verimliliği Derneği tarafindan Ulusal olarak enerji verimliliğinin hem bilgi hem de davranış boyutunda gelişimini tespit etmek üzere "kamuoyunda enerji verimliliği bilinç endeksi" ölçümleyen 
"Enerji Verimliliği bilinç Endeksi Kantitatif Araştırma raporu hazırlanmış ve Mayıs 2020 itibarı ile yayınlanmıştır.

$\mathrm{Bu}$ araştırmanın amacı; Türkiye'de kamuoyunun enerji verimliliğine yönelik bilgi, ilgi ve davranış düzeyini tespit etmek, enerji verimliliği konusunda bilgi, bilinç düzeyi ve uygulama boyutunu arttırmaya yönelik bulgulara ulaşmak, kamuoyunda Enerji Verimliliği Bilinç Endeksi için gerekli KPI'ları (Anahtar Performans Kriterleri) tespit etmektir (ETKB-EVÇED ve ENVER, 2020).

Çalışma kapsamında IBBS-Düzey 2 temsilen aşağıdaki haritada yer alan 26 ildeki kent merkezlerinde ikamet eden 16 yaş üzeri toplamda 3000 kişi ile yüz yüze anket çalışması gerçekleştirilmiştir.

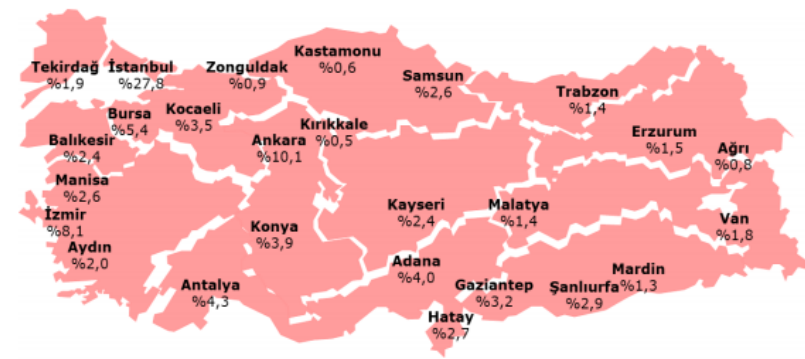

\section{Şekil 3. Araştırmanın Gerçekleştirildiği İller ve Örneklem Dağılımı}

Yapılan bu çalışma kapsamında enerji verimliliğine yönelik bilgi, ilgi ve tutum, davranış gibi boyutlara yönelik endeks değerlerinin belirlenmesi amacıyla gerek demografik gerekse enerji verimliliği sağlamaya yönelik çeşitli önlemlerin bilinip bilinmediği, uygulanıp uygulanmadığı araştırılmıştır. Yapılan bu araştırmada bilgi ve davranış boyutları $\% 50$ oranında ağırlıklandırılarak "Enerji Verimliliği Bilinç Endeksi" hesaplanmıştır.
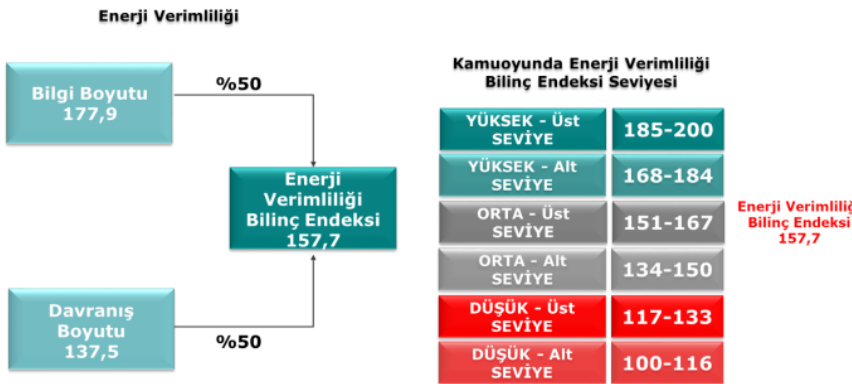

\section{Şekil 4. Enerji Verimliliği Bilinç Endeksi}

Çalışma sonucunda elde edilen veriler üzerinden yapılan analizler aracılığıyla Türkiye genelini temsil eden örneklemin enerji verimliliği bilinç endeksi 0-200 değer aralığında 157,7 olarak elde edilmiştir. Bu değer de kamuoyunun enerji verimliliği konusunda orta-üst seviyede bilinç düzeyi olduğunu göstermektedir. Kamuoyunda Enerji Verimliliği Bilgi Boyutu 177,9 olarak tespit edilmiştir. Bu değer, kamuoyunun enerji verimliliği konusunda yüksek-alt seviyede bilgi düzeyi olduğunu göstermektedir. Kamuoyunda Enerji Verimliliği Davranış Boyutu ise 137,5 olarak tespit edilmiştir. Bu değer, enerji verimliliği konusunda davranış boyutunun orta-alt seviyede olduğunu ifade etmektedir. Bilginin davranışa dönüşündeki açıklık, ilgili tüm paydaşlar ile çalışılması gereken gelişim alanını ortaya koymaktadır.

\section{Sonuç}

$\mathrm{Bu}$ makalede, enerji verimliliği ve enerji tasarrufu konularının tüketiciler tarafından nasıl değerlendirildiği ve bu farkındalık düzeyinin arıtılmasına yönelik Dünya genelinde yapılmış uygulamalar incelenmiştir.

Enerji verimliliğini sağlamak ve devamlı kılmak birçok faaliyet ile mümkündür. $\mathrm{Bu}$ faaliyetlerin çoğu teknolojik müdahaleleri içerir, ancak enerji tüketimindeki farkındalıklar da dahil olmak üzere bazı önlemler tüketici davranışlarına dayanmaktadır. Tüketiciler arasında enerji tasarrufu bilincini vurgulamak iki ana bileşen olan bilgi ve uygulama ile sağlanabilmektedir.

Tüketici davranışlarında değişiklik yapılması hedeflendiğinde davranışlarının hangi parametrelerden etkilendiğini bilmek de oldukça önemli bir konudur. İnsan davranışı dinamiktir ve insan sosyal bir varlıktır. $\mathrm{Bu}$ nedenle tüketicilerin davranışlarını etkileyen birtakım faktörler incelenmiş ve bunların çeşitli fizyolojik, psikolojik ve sosyal faktörler olduğu ortaya konmuştur. Bu anlamda gerek kişilerin konfor tercihleri, dış ortam sıcaklıkları, yaş-gelir düzeyi vb. gibi demografik faktörler, enerji fiyatlandırması, binanın tipi ya da tasarımı gibi birçok alt faktör kişiden kişiye göre değişmekte ve tüketicilerin davranışlarını etkilemektedir. Bu nedenle de tüketici davranışlarını değiştirmeye yönelik yapılacak çalışmada bu faktörler göz önünde bulundurulmalidir.

Dünya'da ve Türkiye'de tüketici davranışlarının değişmesiyle enerji verimliliği sağlanması konusunda yapılmış birçok çalışma incelenmiştir. Bu doğrultuda, enerji verimliliği teknoloji odaklı bir kavramdır. Enerji verimliliği sağlayan uygulamalar ve cihazlar teknolojik yenilikler vasıtasıyla gerçekleştirilmiş ve tüketicilere sunulmuştur. Tüketicilerin enerji tasarrufu etmesi ve enerji verimliliğini artırmasına yönelik farklı yöntemler mevcuttur. Tüketiciler, enerji verimliliği sağlayan ürünler sayesinde tasarruf edebilecekleri gibi çeşitli geri bildirim mekanizmaları vasıtasıyla enerji farkındalığını artırabilir ve tasarruf sağlayabilirler.

Enerji verimliliğinde tüketici algısı ile ilgili yapılmış uygulamalarda kişilerin enerji verimliliği konusundaki bilgi, ilgi ve tutum düzeyi ile bunları ne ölçüde davranışlarına yansıttıkları da ortaya konulmuştur. Tüketicilerin bir noktaya kadar davranışlarının enerji tasarrufu sağlaması noktasında bilgisi olsa dahi çeşitli sosyal, psikolojik ve fizyolojik faktörlerden kaynaklı olarak enerji verimli davranışı sergileyemedikleri görülmüştür.

$\mathrm{Bu}$ nedenle enerji verimliliği ve tasarrufuna yönelik gerçekleştirilmesi hedeflenen uygulamalarda bu tür parametrelerin de dikkate alınması gerekmekte ve kişilerin bilgi ve davranış düzeyleri arasındaki ilişki unutulmamalıdır.

\section{Teșekkür}

Bu makale, ADM ve GDZ Elektrik Dağıtım AŞ. ile beraber gerçekleştirilen tüketici farkındalığı ile enerji verimliliği sağlanmasına yönelik EPDK destekli ar-ge projesi kapsamında gerçekleştirilen araştırma sonuçlarını içermektedir.

$\mathrm{Bu}$ araştırma süresince vermiş oldukları katkılar adına ADM ve GDZ Elektrik Dağıtım AŞ.'ye teşekkürlerimizi sunarız. Bu çalışmanın ortaya çıkmasındaki katkılarından dolayı Enerji Piyasası Düzenleme Kurumu'na teşekkür ederiz. 


\section{Kaynakça}

BP. (2019). BP Statistical Review of World Energy 2019.

Chen J, A. C. (2014). Assessing occupants' energy load variation through existing wireless network infrastructure in commercial and educational buildings. Energy and Buildings(82), 540-549.

Cohen, J. (1988). Statistical power analysis for the behavioral sciences. New Jersey: Lawrence Erlbaum Associates.

EIA. (2019). EIA International Energy Outlook 2019.

ETKB-EVÇED ve ENVER. (2020). Enerji Verimliliği Bilinç Endeksi Kantitatif Araştırma Raporu. EVÇED, ENVER.

European Environment Agency ( EEA). (2013). EEA Technical report: Achieving energy efficiency through behaviour change: what does it take? Denmark: EEA.

Fabi V, A. R. (2012). Occupants' window opening behaviour: a literature review of factors influencing occupant behaviour and models. Build Environ (58), 98-188.

Fragidis, G., \& Detlef , O. (2015). Consumer awareness and engagement for energy efficiency solutions. Berlin: CleopaGmbH.

Future Thinking. (2019). The Effectiveness \& Consumer Experience of In-Home Displays. London: BEAMA.

Gandhi P, B. G. (2016). Commercial office plug load energy consumption trends and the role of occupant behavior. Energy and Buildings(125), 1-8.

Hussain, T. S., Ismail, H., \& Noh, M. (2013). PERKEM Proceedings.

Hussaini, I. U., \& Majid, N. A. (2014). Human behaviour in household energy use and the implications of energy efficiency delivery: A case of Bauchi, Nigeria. International Journal of Energy Sector Management, 8(2), 230-239.

Indraganti M, O. R. (2015). Thermal comfort in offices in India: behavioral adaptation and the effect of age and gender. Energy and Buildings(103), 284-295.

International Energy Agency. (2018). World Energy Outlook 2018. IEA.

MacKay, D. J. (2008). Sustainable Energy - without the hot air. UK: UIT Cambridge.

Majid, N. H., Salehudin, M. S., Rahim, Z. A., \& Othman, R. (2016). Procedia - Social and Behavioral Sciences, 170, 527. MATEC Web Conf.Volume 78, 2016 2nd International Conference on Green Design and Manufacture 2016 (IConGDM 2016).

Martinaitis V, Z. E. (2015). Importance of occupancy information when simulating energy demand of energy efficient house: a case study. Energy and Buildings(101), 64-75.

N.H. Abdul Majid, H. I. (2011). Third International Conference on Applied Energy.

Park JS, K. H. (2012). A field study of occupant behavior and energy consumption in apartments with mechanical ventilation. Energy and Buildings(2012), 19-25.

Rahman, K. A., Leman, A. M., Yusof, M. M., \& Salleh, M. N. (2016). Consumer Awareness in Energy Efficiency for Residential Houses in Peninsular Malaysia. MATEC Web of Conferences 78.

Rijal HB, H. M. (2013). Investigation of comfort temperature, adaptive model and the window-opening behaviour in Japanese houses. Architectural Science Review(56), 54-69.

Rijal HB, T. P. (2011). An algorithm to represent occupant use of windows and fans including situation-specific motivations and constraints. Journal of Building Performance Simulation(4), 34-117.

Tetlow RM, v. d. (2015). Identifying behavioural predictors of small power electricity consumption in office buildings. Build Environ(92), 75-85.

Topal, A., \& Özoğlu, B. (2018). Enerji Verimliliği ve Enerji Tasarrufunun Sürdürülebilir Tüketim Perspektifinden Değerlendirilmesi. 5th International Congress on Political, Economic and Social Studies (ICPESS). Niğde.

Turhan, Ö., Yıldız, S., Ediger, V., Bayraktaroğlu, P. D., Ediger, P. D., Kılınç, D. İ., . . . Filinte, M. (2010). Türkiye Enerji ve Enerji Verimliliği Çalışmalarl Raporu. TEVEM;ENVERDER.

Ueno, T., Inada, R., Saeki, O., \& Tsuji, K. (2006). Effectiveness of an energy consumption information system for residential buildings. Applied Energy, 83(8), 868-883. 